\title{
Platform-wide shift to microbial carbonate production during the late Aptian
}

\author{
K. Schmitt ${ }^{1}$, U. Heimhofer ${ }^{1}$, G. Frijia ${ }^{2}$, and S. Huck ${ }^{1}$ \\ IInstitute of Geology, Leibniz University Hannover, Callinstraße 30, 30167 Hannover, Germany \\ 2Department of Physics and Earth Science, University of Ferrara, Via Giuseppe Saragat 1, 44122 Ferrara, Italy
}

\begin{abstract}
In the aftermath of major Phanerozoic biocrises, diverse metazoan-dominated reef ecosystems were commonly replaced by microbial carbonate-producing communities. Apart from the loss of metazoan competitors, the factors causing pervasive microbial carbonate production in shallow-water platform settings are not completely understood. Amongst others, outstanding warm temperatures coupled with low-oxygen waters were proposed as possible triggers. This study focuses on late Aptian shallow marine carbonates deposited on the Apennine carbonate platform (ACP) in the central Tethys. By establishing an integrated high-resolution chemostratigraphic framework for two sections of the ACP, the coeval onset of pervasive bacinelloid growth is discovered, indicating a platform-wide shift from a metazoan-dominated ecosystem to microbial carbonate production. The initial phase of microbial proliferation coincides with the final stage of the so-called late Aptian "cold snap" and the subsequent temperature increase, which was paralleled by a significant sea-level rise. Our results contrast with observations from the early Aptian Oceanic Anoxic Event 1a, where a similar shift toward microbial "bacinelloid" carbonate production has been linked to exceptionally warm conditions and hypoxia.
\end{abstract}

\section{INTRODUCTION}

Most Phanerozoic reefal and carbonate platform ecosystems were composed of both microbial and skeletal organisms in a mutually beneficial relationship (Webb, 1996). In the aftermath of major biocrises, however, biodiverse metazoan-dominated reef ecosystems were commonly replaced by microbial carbonate-producing communities (e.g., Pomar and Hallock, 2008). Following the end-Permian mass extinction, for instance, the delayed recovery of metazoan grazers caused widespread microbialite formation in subtidal settings (Schubert and Bottjer, 1992). This reorganization of shallow-water carbonate ecosystems is seen as a biological feedback to environmental pressure caused by Siberian Traps volcanism (Pietsch and Bottjer, 2014). It seems likely that the exclusive dominance of neritic microbialite production was fostered by low dissolved oxygen levels in combination with enhanced nutrient availability, exceptionally warm sea-surface temperatures (SSTs), and high $p \mathrm{CO}_{2}$ levels (e.g., Sun et al., 2012; Kershaw et al., 2012).

A similar set of environmental stressors may have acted on marine calcifying organisms dur- ing the mid-Cretaceous emplacement of the Ontong Java Plateau large igneous province (OJP-LIP; Erba et al., 2015). Biotic feedbacks to early Aptian OJP-LIP-related environmental perturbations include a crisis amongst calcareous nannoplankton (Erba et al., 2010), the demise and drowning of subtropical carbonate platforms (Föllmi et al., 1994), the widespread burial of organic matter (e.g., Jenkyns, 2010) during the Oceanic Anoxic Event (OAE) 1a, and the coeval dominance of Lithocodium-Bacinella microencrusters in Tethyan shallow-water settings at the expense of coral-rudist platform communities (Immenhauser et al., 2005; Huck et al., 2010). The taxonomic position of Lithocodium aggregatum, Bacinella irregularis, and "lithocodoid" and "bacinelloid" fabrics is still under debate, but it is widely accepted that these microproblematica (problematic fossil bodies of organic origin but unknown classification) should be attributed to encrusting algal ( $L . a g$ gregatum) and calcimicrobial (B. irregularis) communities (Huck et al., 2012), respectively.

Mass occurrences of shallow-water Lithocodium-Bacinella microencrusters have been linked to short-lived global warming (hyper- thermal) events, probably in combination with platform hypoxia (Huck et al., 2012; Hüter et al., 2019) as suggested for comparable microbial episodes during times of mass extinctions. Isolated Lithocodium and/or Bacinella occurrences, however, were also reported from various late Aptian and early-middle Albian shallow-water settings (e.g., Neuweiler and Reitner, 1992; Gréselle and Pittet, 2005; Waite et al., 2007; Di Lucia et al., 2012), but these microbial episodes commonly lack a precise stratigraphic assignment, which would enable their placement into a global context of environmental change.

The current study documents multiple pulses of pervasive bacinelloid microencruster growth in two Tethyan carbonate platform sections (Apennines, Italy) covering the Aptian-Albian boundary interval. The overall aim is to chemostratigraphically $(\mathrm{C}, \mathrm{Sr})$ pinpoint the onset of bacinelloid mass occurrences and to capture the spatial and temporal patterns of carbonate platform ecology change.

\section{GEOLOGICAL SETTING}

During the mid-Cretaceous, the Apennine carbonate platform (ACP; Fig. 1A) was one of several isolated central Tethyan carbonate platforms bordered by the Molise-Sannio-Lagonegro basin in the north (Fig. 1B) at a paleolatitude of $\sim 15^{\circ} \mathrm{N}$. The studied 153 -m-thick Santa Lucia $\left(41^{\circ} 31^{\prime} 00.6^{\prime \prime} \mathrm{N} 13^{\circ} 46^{\prime} 40.0^{\prime \prime} \mathrm{E}\right)$ and 166-m-thick Monte La Costa $\left(41^{\circ} 28^{\prime} 12.4^{\prime \prime} \mathrm{N}\right.$ $\left.14^{\circ} 29^{\prime} 50.0^{\prime \prime} \mathrm{E}\right)$ shallow-water successions represent back-reef and platform-margin settings of the ACP, respectively, and are largely composed of thick-bedded peloidal-bioclastic and foraminiferal grain- and rudstones with mudsupported intercalations. The typical platform biota comprises radiolitid rudists, chondrodonts, gastropods, benthic foraminifers including orbitolinids, dasycladacean algae, and solitary corals. A remarkable feature characterizing both the Santa Lucia and Monte La Costa sections

CITATION: Schmitt, K., Heimhofer, U., Frijia, G., and Huck, S., 2019, Platform-wide shift to microbial carbonate production during the late Aptian: Geology, https://doi.org/10.1130/G46325.1 


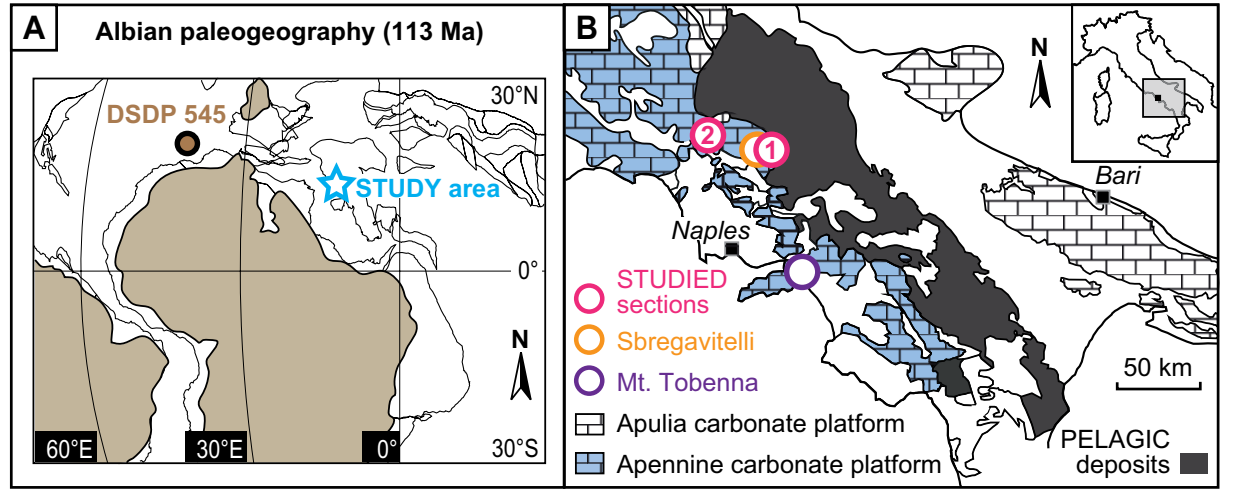

Figure 1. A: Albian palaeogeographic map (modified after Huber and Leckie, 2011) with the location of the central Tethyan study area and North Atlantic Deep Sea Drilling Project (DSDP) Site 545. B: Locations of considered Apennine carbonate platform sections, including Santa Lucia (1) and Monte La Costa (2), as well as Sbregavitelli and Monte Tobenna (modified after Frijia and Parente, 2008).

is the repeated pervasive growth of bacinelloid microencrusters. Biostratigraphically, the studied limestone deposits are assigned to the Aptian-Albian "calcari con requienie e gasteropodi” formation (Di Stefano et al., 2011).

\section{METHODS}

Samples for microfacies and geochemical investigations were taken at a spacing of $\sim 0.5-1 \mathrm{~m}$. Bacinelloid microencrusters were studied and semi-quantitatively analyzed in 55 petrographic thin sections. The differentiation of bacinelloid morphotypes is based on the classification scheme of Rameil et al. (2010) and Huck et al. (2012).

The most fine-grained portion of 436 bulk carbonate samples was sampled with a handheld micro-drill and measured for its carbon and oxygen isotope composition at the Institute of Geology at Leibniz University Hannover, Germany (Tables DR1 and DR2 in the GSA Data Repository $\left.{ }^{1}\right)$. Certified carbonate standards (NBS 19 [limestone], NBS 18 [calcite], IAEA-CO-1 [marble]) produce an external reproducibility of $0.08 \%$ for $\delta^{18} \mathrm{O}$ and $0.06 \%$ o for $\delta^{13} \mathrm{C}$. All isotope results are reported in per mil relative to the Vienna Pee Dee belemnite (VPDB) standard in the conventional delta notation. For Sr-isotope analyses, the preservation state of outer shell layers of low-Mg calcite bivalve shells (rudists: $n=5$; chondrodonts: $n=3$ ) was assessed by elemental compositions $(\mathrm{Ca}, \mathrm{Mg}, \mathrm{Sr}, \mathrm{Fe}$, and $\mathrm{Mn}$ ) provided by inductively coupled plasma-atomic emission spectrometry at the Institute of Geology, Mineralogy and Geophysics at Ruhr-University Bochum (RUB), Germany. In total, five rudist and three chondrodont shells were analyzed at RUB for ${ }^{87} \mathrm{Sr} /{ }^{86} \mathrm{Sr}$ ratios using a Finnigan MAT

${ }^{1}$ GSA Data Repository item 2019279, isotope and elemental compositions of bulk carbonate and selected rudist shell materials, is available online at http://www .geosociety.org/datarepository/2019/, or on request from editing@geosociety.org.
262 thermal ionization mass spectrometer in dynamic mode. Refer to Huck et al. (2010) for more details of the analytical procedure.

\section{RESULTS}

Bacinelloid fabrics are characterized by differently sized and shaped sparite-filled vesicles or "cells" (Schlagintweit et al., 2010) that form either (I) oncoids (layered structures formed by cyanobacterial growth) (diameter, $\varnothing, 250 \mu \mathrm{m}$ to $5 \mathrm{~cm}$ ), (II) irregular shaped centimeter-sized patches, or (III) massive crusts (Fig. 2). In the inner carbonate platform domain - covered by the Santa Lucia section - the dominance of bacinelloid microencrusters is demonstrated by the intermittent occurrence of meter-thick beds of float- and rudstones bearing bacinelloid morphotypes I and II (Fig. 3, 58-75 m, 124-148 m). The size and volumetric abundance of morphotype I are strongly variable, the distribution of which includes stratigraphic levels comprising smallsized, dispersed or centimeter-sized amalgamated (condensed) and partly reworked oncoids. At the platform margin represented by the Monte La
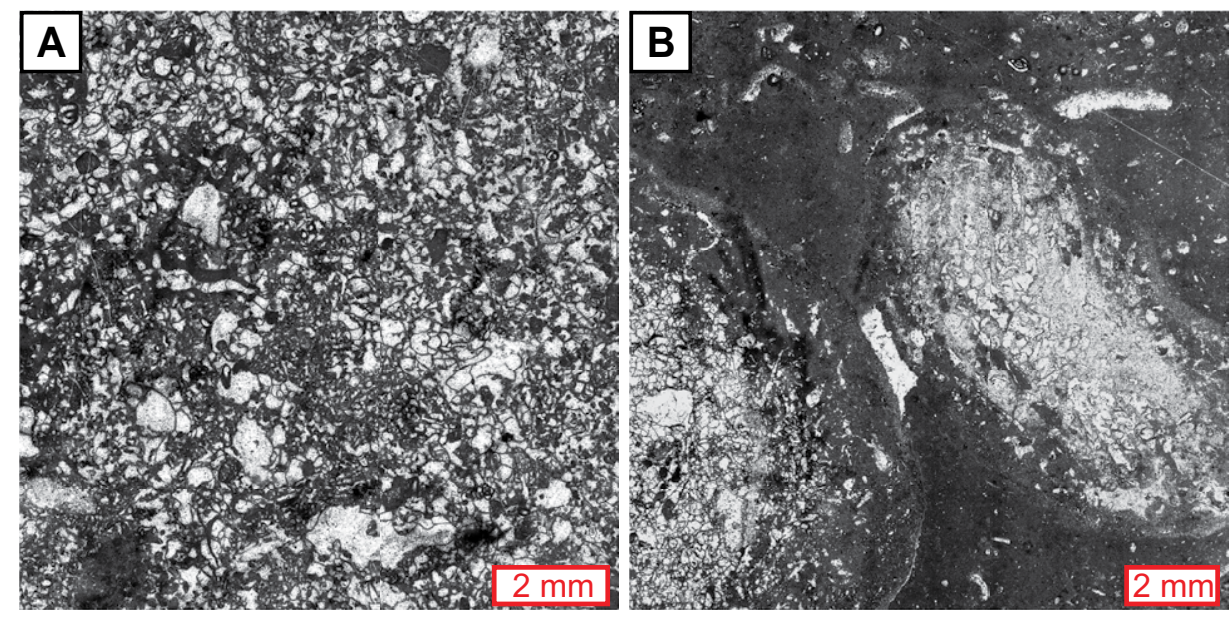

Figure 2. Microphotographs of massive (morphotype III) (A) and oncoidal (morphotype I) (B) bacinelloid morphotypes.
Costa section, massive bacinelloid boundstone facies types (morphotype III) occur at several stratigraphic intervals (Fig. 3, 27-74 m, 124-140 m). In contrast to the Santa Lucia locality, morphotypes I and II are rare or absent.

Both sections, although distributed $\sim 60 \mathrm{~km}$ apart, show a remarkably similar stratigraphic $\delta^{13} \mathrm{C}$ pattern (Fig. 3) characterized by a doublepeaked positive carbon isotope excursion (CIE) reaching up to $4.5 \%$ (Monte La Costa). The CIE is followed by sinusoidal $\delta^{13} \mathrm{C}$ variations (amplitude of 1\%o) that are superimposed on a gradual negative trend. Strontium-isotope ratios recorded by bivalve shell calcite range between $0.707194\left( \pm 5 \times 10^{-6}\right)$ and $0.707316( \pm$ $\left.5 \times 10^{-6}\right)$, exhibiting a pattern indicative of the latest Aptian-earliest Albian interval (ca. 115$111 \mathrm{Ma}$; McArthur et al., 2001). The pristine preservation state of considered bivalve shells is proven both by well-defined growth increments composed of fibrous low-Mg calcite as well as elemental characteristics such as high $\mathrm{Sr}$ (rudists mean: 1161 ppm; chondrodonts mean: 676 ppm) and low Mn (rudists mean: 4 ppm; chondrodonts mean: $5 \mathrm{ppm}$ ) and $\mathrm{Fe}$ (rudists mean: $1 \mathrm{ppm}$; chondrodonts mean: $3 \mathrm{ppm}$ ) concentrations (Table DR3).

\section{DISCUSSION}

\section{Platform-Wide Expansion of Microbial Carbonate Production}

Considering the chemostratigraphic findings, a pronounced change in facies toward an overwhelming dominance of bacinelloid microencrusters starts in the upper part of the positive CIE at both sites (Fig. 3). This facies change marks the onset of rapid alternations between pervasive bacinelloid microencruster growth and typical photozoan carbonate production. At the Santa Lucia site, the initial onset and major phase of bacinelloid microencruster growth corresponds to an $\sim 17$-m-thick package essentially 
Santa Lucia section - inner platform domain

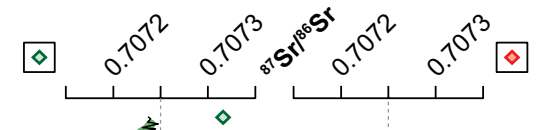

Monte La Costa section - platform margin

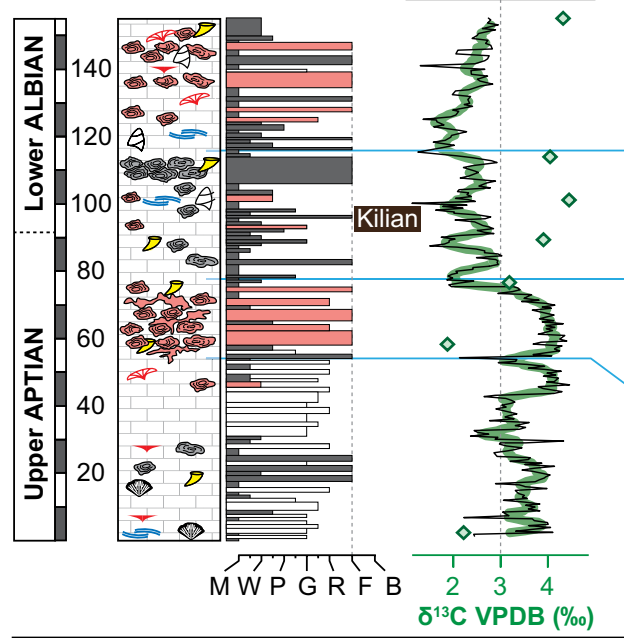

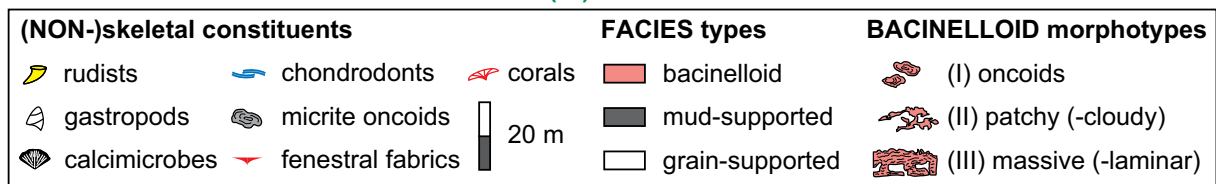

Figure 3. Comparative facies characteristics, lithostratigraphy, and chemostratigraphy $\left(\delta^{13} \mathrm{C}\right.$, curves; ${ }^{87} \mathrm{Sr} /{ }^{86} \mathrm{Sr}$, diamonds) of Santa Lucia and Monte La Costa sections of the Apennine carbonate platform (central Italy). Correlation of both sections (blue lines) is based on characteristic carbon-isotope trends and inflexion points. Green and red bold lines represent five-point moving average curves. Kilian - pelagic organic-rich level. B-boundstone; F-floatstone; G-grainstone; M-mudstone; $P$-packstone; R-rudstone; W-wackestone; VPDB-Vienna Peedee belemnite.

composed of morphotypes I and II. Here, the dominance of large bacinelloid oncoids points to low hydrodynamic conditions coupled with reduced sedimentation rates in a lagoonal setting (Védrine et al., 2007). At the Monte La Costa site, the second peak of the CIE correlates with an 47-m-thick unit composed of massive bacinelloid morphotype III. The dominance of massive crusts at the platform margin provides evidence that bacinelloid microencrusters developed morphological strategies for growth under high-energy conditions. These interpretations are in line with early Aptian Lithocodium-Bacinella microencruster morphotypes identified along the Arabian carbonate platform, where delicate, autochthonous morphotypes characterize calm deeper-water environments and more robust or reworked forms are typically found in highenergy settings (Rameil et al., 2010). Following an initial phase of pronounced growth, the overlying beds are characterized by more intermittent and successively declining bacinelloid occurrence at both study sites.

A platform-wide and synchronous ecosystem shift toward microbial dominance is supported by comparison with existing studies from the ACP. Di Lucia et al. (2012) documented an uppermost Aptian interval rich in LithocodiumBacinella nodules of subtidal open lagoon facies from the Monte Tobenna section, located $90 \mathrm{~km}$ south of the Monte La Costa site (Fig. 1B). In the Sbregavitelli section in the vicinity of Monte La Costa (central ACP; Fig. 1B), large reworked Lithocodium-Bacinella oncoids form part of upper Aptian channel-fill deposits (Ruberti et al., 2013). In summary, the contemporaneous invasion of bacinelloid microencrusters into lagoonal as well as marginal carbonate platform settings resulted in a fundamental change in shallow-water platform ecology and carbonate production mode and highlights their role as ecological generalists.

\section{Implications for Mid-Cretaceous \\ Lithocodium-Bacinella Mass Occurrences}

The new geochemical results enable stratigraphic correlation with a well-dated pelagic reference $\delta^{13} \mathrm{C}$ record from the Umbria Marche Basin in central Italy (Piobbico core, drilled in 1982 by the Italian Consiglio Nazionale Delle Ricerche; Bottini et al., 2015) and show that the onset of pervasive bacinelloid microencruster growth on the ACP falls within the uppermost portion of a prolonged late Aptian positive CIE (Fig. 4). Strontium isotope ratios indicate that

\section{UMBRIA MARCHE BASIN $\quad 28 \quad 30 \quad 32 \quad$ SST $\left({ }^{\circ} \mathrm{C}\right)$}

APENNINE PLATFORM

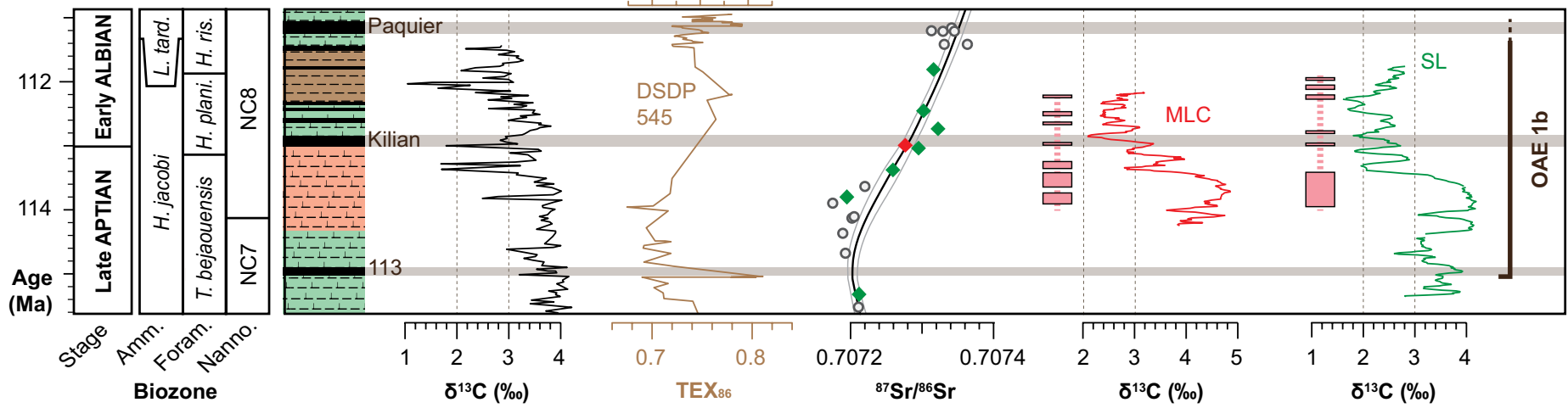

Figure 4. Correlation of Santa Lucia (SL) and Monte La Costa (MLC) (sections of the Apennine carbonate platform) carbon-isotope profiles with well-dated pelagic composite $\delta^{13} \mathrm{C}$ record from Umbria Marche Basin, central Italy (Piobicco core, drilled in 1982 by the Italian Consiglio Nazionale Delle Ricerche; Bottini et al., 2015). Sea-surface temperature (SST) estimates are based on TEX ${ }_{86}$ data from Deep Sea Drilling Project (DSDP) Site 545 (McAnena et al., 2013). Evolution of global marine ${ }^{87} \mathrm{Sr} /{ }^{86} \mathrm{Sr}$ values, including $95 \%$ confidence bounds, is from McArthur et al. (2001). Diamonds refer to ${ }^{87} \mathrm{Sr} /{ }^{86} \mathrm{Sr}$ values of pristine rudist shell materials collected at Santa Lucia (green) and Monte La Costa (red). All data are calibrated to the Geologic Time Scale 2012 (Ogg and Hinnov, 2012). Lithostratigraphic log of the Piobbico core (Bottini et al., 2015) comprises pelagic organic-rich levels referred to as 113 (Jacob), Kilian, and Paquier episodes (black), marlstones (green), pink to reddish marlstones (red), and claystones (brown). The stratigraphic distribution of bacinelloid microencrusters is indicated by pinkish bars. Ammonite biozones: $\boldsymbol{H}$. jacobi-Hypacanthoplites jacobi; L. tard._Leymeriella tardefurcata. Foraminiferal biozones: T. bejaouaensis-Ticinella bejaouaensis; H. planispira-Hedbergella planispira; H. risch-Hedbergella rischi. NC7/8-Nanno(conid) biozones 7 and 8. 
the platform-wide ecosystem turnover slightly postdates the late Aptian minimum of the global marine ${ }^{87} \mathrm{Sr} /{ }^{86} \mathrm{Sr}$ composite record (McArthur et al., 2001). Considering the Geologic Time Scale 2012 (Ogg and Hinnov, 2012), the ${ }^{87} \mathrm{Sr} /{ }^{86} \mathrm{Sr}$ minimum can be placed at ca. $115 \mathrm{Ma}$ (Hypacanthoplites jacobi ammonite zone), stratigraphically positioned between the 113 (Jacob) and Kilian black-shale levels of the OAE $1 \mathrm{~b}$ multi-event.

The initial expansion of bacinelloid-dominated facies occurred during a phase of peculiar climatic conditions referred to as the late Aptian "cold snap" (Mutterlose et al., 2009; Millán et al., 2014; Bodin et al., 2015; O’Brien et al., 2017). Open-ocean SST estimates based on $\mathrm{TEX}_{86}$ data from the eastern North Atlantic (Deep Sea Drilling Project Site 545: McAnena et al., 2013; Fig. 4) show a distinct drop from $\sim 32{ }^{\circ} \mathrm{C}$ during the early late Aptian (NC7B nanofossil zone) toward $\sim 28{ }^{\circ} \mathrm{C}$ in the latest Aptian (NC8A), compared to exceptionally warm $\mathrm{TEX}_{86}$-derived SST estimates of $\sim 34{ }^{\circ} \mathrm{C}$ prevailing during the middle Albian (O'Brien et al., 2017). Additional but arguable evidence for global cooling during the late Aptian is provided by the southward migration of boreal taxa (Mutterlose et al., 2009) and glendonite occurrences at high latitudes (Herrle et al., 2015; Grasby et al., 2017).

In the Piobbico core, the stratigraphic interval between the 113 and Kilian levels is composed of organic-poor, red-colored marlstone indicative of well-oxygenated and probably cool bottom waters (Bottini and Erba, 2018). Chemostratigraphic correlation reveals that the main phase of bacinelloid growth on the ACP took place during the final stage of the late Aptian SST minimum and the subsequent temperature increase (Fig. 4). Individual black-shale levels indicative of basinal anoxia and associated with short-lived hyperthermal conditions (McAnena et al., 2013; Bottini and Erba, 2018) show no clear lithological expression in the shallowwater deposits on the ACP. This clearly contrasts with early Aptian Lithocodium-Bacinella episodes related to OAE 1a, which were proposed to be associated with shallow-water platform hypoxia during a phase of global ocean oxygen deficiency (Hüter et al., 2019).

At the Monte La Costa site, deposition of the bacinelloid interval postdates an unconformity, which marks a significant late Aptian hiatus (Graziano and Raspini, 2015). Evidence for widespread platform exposure due to a late Aptian sea-level drop of arguable glacio-eustatic nature comes from Iberia and the Arabian plate, where deeply incised valley systems were backfilled with locally condensed iron-rich siliciclastics (Gréselle and Pittet, 2005; Maurer et al., 2013; Bover-Arnal et al., 2014; Millán et al., 2014). According to Maurer et al. (2013), the long-lasting late Aptian lowstand was followed by a rapid sea-level rise in the range of $\sim 40 \mathrm{~m}$. On the Arabian plate, this subsequent sea-level rise has been placed in the Aptian sequence APT6 (third-order sequence) which corresponds to the stratigraphic interval located between the 113 (Jacob) and Paquier levels (H. jacobi ammonite zone). These observations indicate that the onset of sedimentation at the Monte La Costa site may reflect the APT6 sea-level rise, with the massive bacinelloid deposits representing a transgressive facies associated with lowered light and enhanced nutrient levels (Whalen et al., 2002; Huck et al., 2012).

Building on the here-established robust stratigraphic framework, pervasive bacinelloid microencruster growth on the ACP occurred during a phase of climatic transition at the end of the late Aptian cooling $\left(\right.$ TEX $_{86}$ SSTs between 27 and $32{ }^{\circ} \mathrm{C}$ ). This observation contrasts with shallow-water Lithocodium-Bacinella microbial episodes during OAE 1a, the onset of which is considered a hyperthermal episode TEX $_{86}$ SST $<34{ }^{\circ} \mathrm{C}$; Mutterlose et al. 2014; Jenkyns, 2018). The rock-forming dominance of microencrusters on the ACP is not primarily an expression of exceptionally warm SSTs. In contrast, the platform-wide shift to microbial bacinelloid carbonate production was likely governed by the flooding of platform tops by cool and nutrientrich waters associated with a late Aptian thirdorder sea-level rise.

\section{ACKNOWLEDGMENTS}

We thank Christiane Wenske (Leibniz University Hannover) for laboratory assistance, and Fritz-Lukas Stoepke (Leibniz University Hannover) for thin-section preparation. Financial support from German Research Foundation (DFG) projects HU 2258/2-1 (Huck) and HE 4467/8-1 (Heimhofer) is gratefully acknowledged. Furthermore, we would like to thank K. Föllmi, $\mathrm{H}$. Weissert, and two anonymous reviewers for their critical comments and constructive contributions.

\section{REFERENCES CITED}

Bodin, S., Meissner, P., Janssen, N.M.M., Steuber, T., and Mutterlose, J., 2015, Large igneous provinces and organic carbon burial: Controls on global temperature and continental weathering during the Early Cretaceous: Global and Planetary Change, v. 133 , p. $238-253$, https://doi.org/10 $.1016 /$ j.gloplacha.2015.09.001.

Bottini, C., and Erba, E., 2018, Mid-Cretaceous paleoenvironmental changes in the western Tethys: Climate of the Past, v. 14, p. 1147-1163, https://doi .org/10.5194/cp-14-1147-2018.

Bottini, C., Erba, E., Tiraboschi, D., Jenkyns, H.C., Schouten, S., and Sinninghe Damsté, J.S., 2015, Climate variability and ocean fertility during the Aptian Stage: Climate of the Past, v. 11, p. 383 4022, https://doi.org/10.5194/cp-11-383-2015.

Bover-Arnal, T., Salas, R., Guimerà, J., and MorenoBedmar, J.A., 2014, Deep incision in an Aptian carbonate succession indicates major sea-level fall in the Cretaceous: Sedimentology, v. 61 , p. 1558-1593, https://doi.org/10.1111/sed.12105.

Di Lucia, M., Trecalli, A., Mutti, M., and Parente, M., 2012, Bio-chemostratigraphy of the BarremianAptian shallow-water carbonates of the southern Apennines (Italy): Pinpointing the OAE1a in a
Tethyan carbonate platform: Solid Earth, v. 3, p. 1-28, https://doi.org/10.5194/se-3-1-2012.

Di Stefano, R., Fiorentino, A., Marino, M., and Perini, P., 2011, Verso uno schema litostratigrafico dell'Appennino meridionale: Rendiconti online della Società Geologica Italiana, v. 12, p. 59-61.

Erba, E., Bottini, C., Weissert, H.J., and Keller, C.E., 2010, Calcareous nannoplankton response to surface-water acidification around Oceanic Anoxic Event 1a: Science, v. 329, p. 428-432, https://doi .org/10.1126/science.1188886.

Erba, E., Duncan, R.A., Bottini, C., Tiraboschi, D., Weissert, H., Jenkyns, H.C., and Malinverno, A., 2015, Environmental consequences of Ontong Java Plateau and Kerguelen Plateau volcanism, in Neal, C.R, et al., eds., The Origin, Evolution, and Environmental Impact of Oceanic Large Igneous Provinces: Geological Society of America Special Paper 511, p. 271-303, https://doi.org/10 $.1130 / 2015.2511(15)$.

Föllmi, K.B., Weissert, H., Bisping, M., and Funk, H., 1994, Phosphogenesis, carbon-isotope stratigraphy, and carbonate-platform evolution along the Lower Cretaceous northern Tethyan margin: Geological Society of America Bulletin, v. 106, p. 729-746, https://doi.org/10.1130/0016-7606 (1994) 106<0729:PCISAC >2.3.CO;2.

Frijia, G., and Parente, M., 2008, Strontium isotope stratigraphy in the upper Cenomanian shallowwater carbonates of the southern Apennines: Short-term perturbations of marine ${ }^{87} \mathrm{Sr} /{ }^{86} \mathrm{Sr}$ during the oceanic anoxic event 2: Palaeogeography, Palaeoclimatology, Palaeoecology, v. 261, p. 1529, https://doi.org/10.1016/j.palaeo.2008.01.003.

Grasby, S.E., McCune, G.E., Beauchamp, B., and Galloway, J.M., 2017, Lower Cretaceous cold snaps led to widespread glendonite occurrences in the Sverdrup Basin, Canadian High Arctic: Geological Society of America Bulletin, v. 129, p. 771-787, https://doi.org/10.1130/B31600.1.

Graziano, R., and Raspini, A., 2015, Long-and shortterm hydroclimatic variabilities in the Aptian Tethys: Clues from the orbital chronostratigraphy of evaporite-rich beds in the Apennine carbonate platform (Mt. Faito, southern Italy): Palaeogeography, Palaeoclimatology, Palaeoecology, v. 418, p. 319-343, https://doi.org/10.1016/j.palaeo.2014 .11 .021 .

Gréselle, B., and Pittet, B., 2005, Fringing carbonate platforms at the Arabian Plate margin in northern Oman during the Late Aptian-Middle Albian: Evidence for high-amplitude sea-level changes: Sedimentary Geology, v. 175, p. 367-390, https:// doi.org/10.1016/j.sedgeo.2004.11.007.

Herrle, J.O., Schröder-Adams, C.J., Davis, W., Pugh, A.T., Galloway, J.M., and Fath, J., 2015, MidCretaceous High Arctic stratigraphy, climate, and Oceanic Anoxic Events: Geology, v. 43, p. 403406, https://doi.org/10.1130/G36439.1.

Huber, B.T., and Leckie, R.M., 2011, Planktic foraminiferal species turnover across deep-sea Aptian/ Albian boundary sections: Journal of Foraminiferal Research, v. 41, p. 53-95, https://doi.org/10 .2113 gsjfr.41.1.53.

Huck, S., Rameil, N., Korbar, T., Heimhofer, U., Wieczorek, T.D., and Immenhauser, A., 2010, Latitudinally different responses of Tethyan shoal-water carbonate systems to the Early Aptian oceanic anoxic event (OAE1a): Sedimentology, v. 57, p. 1585-1614, https://doi.org/10.1111/j.1365 -3091.2010.01157.x.

Huck, S., Heimhofer, U., and Immenhauser, A., 2012, Early Aptian algal bloom in a neritic proto-North Atlantic setting: Harbinger of global change related to OAE1a?: Geological Society of America Bulletin, v. 124, p. 1810-1825, https://doi.org/10 .1130/B30587.1. 
Hüter, A., Huck, S., Bodin, S., Heimhofer, U., Weyer, S., Jochum, K.P., and Immenhauser, A., 2019, Central Tethyan platform-top hypoxia during Oceanic Anoxic Event 1a: Climate of the Past Discussions, https://doi.org/10.5194/cp-2019-3.

Immenhauser, A., Hillgärtner, H., and van Bentum, E., 2005, Microbial-foraminiferal episodes in the Early Aptian of the southern Tethyan margin: Ecological significance and possible relation to oceanic anoxic event 1a: Sedimentology, v. 52, p. 77-99, https://doi.org/10.1111/j.1365-3091 .2004.00683.x.

Jenkyns, H.C., 2010, Geochemistry of oceanic anoxic events: Geochemistry Geophysics Geosystems, v. 11, Q03004, https://doi.org/10.1029 12009GC002788.

Jenkyns, H.C., 2018, Transient cooling episodes during Cretaceous Oceanic Anoxic Events with special reference to OAE 1a (Early Aptian): Philosophical Transactions of the Royal Society A: Mathematical, Physical and Engineering Sciences, v. 376, 20170073, https://doi.org/10.1098 /rsta.2017.0073.

Kershaw, S., Crasquin, S., Li, Y., Collin, P.Y., Forel, M.B., Mu, X., Baud, A., Wand, Y., Xie, S., Maurer, F., and Guo, L., 2012, Microbialites and global environmental change across the Permian-Triassic boundary: A synthesis: Geobiology, v. 10, p. 25-47, https://doi.org/10.1111 /j.1472-4669.2011.00302.x.

Maurer, F., van Buchem, F.S.P., Eberli, G.P., Pierson, B.J., Raven, M.J., Larsen, P.-H., Al-Husseini, M.I., and Vincent, B., 2013, Late Aptian longlived glacio-eustatic lowstand recorded on the Arabian Plate: Terra Nova, v. 25, p. 87-94, https://doi.org/10.1111/ter.12009.

McAnena, A., Flögel, S., Hofmann, P., Herrle, J.O., Griesand, A., Pross, J., Talbot, H.M., Rethemeyer, J., Wallmann, K., and Wagner, T., 2013, Atlantic cooling associated with a marine biotic crisis during the mid-Cretaceous period: Nature Geoscience, v. 6, p. 558-561, https://doi.org/10.1038 /ngeo1850.

McArthur, J.M., Howarth, R.J., and Bailey, T.R., 2001, Strontium isotope stratigraphy: LOWESS version 3: Best fit to the marine Sr-isotope curve for 0-509 Ma and accompanying look-up table for deriving numerical age: The Journal of Geology, v. 109, p. 155-170, https://doi.org/10.1086 /319243.
Millán, M.I., Weissert, H.J., and López-Horgue, M.A., 2014, Expression of the late Aptian cold snaps and the OAE1b in a highly subsiding carbonate platform (Aralar, northern Spain): Palaeogeography, Palaeoclimatology, Palaeoecology, v. 411, p. 167 179, https://doi.org/10.1016/j.palaeo.2014.06.024.

Mutterlose, J., Bornemann, A., and Herrle, J.O., 2009 The Aptian-Albian cold snap: Evidence for mid Cretaceous icehouse interludes: Neues Jahrbuch für Geologie und Palaontologie, Abhandlungen, v. 252 , p. $217-225$, https://doi.org/10.1127/0077 $-7749 / 2009 / 0252-0217$.

Mutterlose, J., Bottini, C., Schouten, S., and Sinninghe Damsté, J.S., 2014, High sea-surface temperatures during the early Aptian Oceanic Anoxic Event 1a in the Boreal Realm: Geology, v. 42, p. 439-442, https://doi.org/10.1130/G35394.1.

Neuweiler, F., and Reitner, J., 1992, Karbonatbänke mit Lithocodium aggregatum Elliott/Bacinella irregularis Radoičić: Paläobathymetrie, Paläoökologie und stratigraphisches Äquivalent zu thrombolithischen Mud Mounds, Berliner Geowiss: Abhandlungen, v. 3, p. 273-293.

O'Brien, C.L., et al., 2017, Cretaceous sea-surface temperature evolution: Constraints from $\mathrm{TEX}_{86}$ and planktonic foraminiferal oxygen isotopes: Earth-Science Reviews, v. 172, p. 224-247, https://doi.org/10.1016/j.earscirev.2017.07.012.

Ogg, J.G., and Hinnov, L.A., 2012, The Cretaceous Period, in Gradstein, F., et al., eds., The Geologic Time Scale 2012: Amsterdam, Elsevier, p. 793 853, https://doi.org/10.1016/B978-0-444-59425 $-9.00027-5$.

Pietsch, C., and Bottjer, D.J., 2014, The importance of oxygen for the disparate recovery patterns of the benthic macrofauna in the Early Triassic: EarthScience Reviews, v. 137, p. 65-84, https://doi.org /10.1016/j.earscirev.2013.12.002.

Pomar, L., and Hallock, P., 2008, Carbonate factories: A conundrum in sedimentary geology: Earth-Science Reviews, v. 87, p. 134-169, https://doi.org /10.1016/j.earscirev.2007.12.002.

Rameil, N., Immenhauser, A., Warrlich, G., Hillgärtner, H., and Droste, H.J., 2010, Morphological patterns of Aptian Lithocodium-Bacinella geobodies: Relation to environment and scale: Sedimentology, v. 57, p. 883-911, https://doi.org/10 .1111/j.1365-3091.2009.01124.x.

Ruberti, D., Bravi, S., Carannante, G., Vigorito, M., and Simone, L., 2013, Decline and recovery of the Aptian carbonate factory in the southern Apennine carbonate shelves (southern Italy): Climatic/oceanographic vs. local tectonic controls: Cretaceous Research v. 39, v. 112-132, https:// doi.org/10.1016/j.cretres.2012.05.012.

Schlagintweit, F., Bover-Arnal, T., and Salas, R., 2010, New insights into Lithocodium aggregatum Elliott 1956 and Bacinella irregularis Radoičić 1959 (Late Jurassic-Lower Cretaceous): Two ulvophycean green algae (?Order Ulotrichales) with a heteromorphic life cycle (epilithic/euendolithic): Facies, v. 56, p. 509-547, https://doi.org /10.1007/s10347-010-0222-4.

Schubert, J.K., and Bottjer, D.J., 1992, Early Triassic stromatolites as post-mass extinction disaster forms: Geology, v. 20, p. 883-886, https:// doi.org/10.1130/0091-7613(1992)020<0883: ETSAPM $>2.3 . \mathrm{CO} ; 2$.

Sun, Y., Joachimski, M.M., Wignall, P.B., Yan, C., Chen, Y., Jiang, H., Wang, L., and Lai, X., 2012, Lethally hot temperatures during the Early Triassic greenhouse: Science, v. 338, p. 366-370, https://doi.org/10.1126/science.1224126.

Védrine, S., Strasser, A., and Hug, W., 2007, Oncoid growth and distribution controlled by sea-level fluctuations and climate (Late Oxfordian, Swiss Jura Mountains): Facies, v. 53, p. 535-552, https://doi.org/10.1007/s10347-007-0114-4.

Waite, L.E., Scott, R.W., and Kerans, C., 2007, Middle Albian age of the regional dense marker bed of the Edwards Group, Pawnee Field, south-central Texas: Gulf Coast Association of Geological Societies Transactions, v. 57, p. 759-774.

Webb, G.E., 1996, Was Phanerozoic reef history controlled by the distribution of non-enzymatically secreted reef carbonates (microbial carbonate and biologically induced cement)?: Sedimentology, v. 43, p. 947-971, https://doi.org/10.1111/j.1365 -3091.1996.tb01513.x.

Whalen, M.T., Day, J., Eberli, G.P., and Homewood, P.W., 2002, Microbial carbonates as indicators of environmental change and biotic crises in carbonate systems: Examples from the Late Devonian, Alberta basin, Canada: Palaeogeography, Palaeoclimatology, Palaeoecology, v. 181, p. 127-151, https://doi.org/10.1016/S0031-0182 (01)00476-X.

Printed in USA 